\title{
A Preliminary List and Description of the Nyāyamañjarī Manuscripts
}

\author{
Alessandro Graheli
}

Published online: 20 May 2012

(C) The Author(s) 2012. This article is published with open access at Springerlink.com

\begin{abstract}
The present paper is an inventory and a description of the known manuscripts of the Nyāyamañjarī, meant as a tool for philological research on Bhatța Jayanta's magnum opus. The inventory is gradually built through a systematic analysis of archival data found in catalogi catalogorum, bibliographies of catalogues, individual catalogues, unpublished lists, and editions of the Nyāyamañjarī. The list is followed by a concise description of each manuscript, including an external description, an outline of the contents, and historical information.
\end{abstract}

Keywords Jayanta Bhaț̣a $\cdot$ Śitikaṇtha $\cdot$ Nyāyamañjarī $\cdot$ Nyāya $\cdot$

Śāradā · Kashmir · Manuscriptology · Codicology · Textual criticism • Manuscript catalogues · Manuscript description · Catalogus Catalogorum

A critical edition, regardless of the chosen editorial method, requires a solid documentary foundation, which begins from an accurate and thorough inventory of all the textual material potentially available. ${ }^{1}$ The present paper is meant to facilitate and encourage the philological research of scholars who intend to study the Nyāyamañjarī of Bhatța Jayanta (NM) by providing a list and disambiguation of the known manuscript sources of the NM, as well as a concise description of these sources.

An inventory of the existing manuscripts and editions is an indispensable foundation of any well documented critical edition. Thorough inventories and descriptions, however, are seldom found in introductions to editions, due to at least

\footnotetext{
1 The demonstration of the importance of a sound documentary basis was one of Lachmann's great achievements, explains Timpanaro (2003, p. 88): “[...] primum recensere!”.
}

A. Graheli $(\bowtie)$

Department of South Asian Tibetan and Buddhist Studies (ISTB),

University of Vienna, Vienna, Austria

e-mail: a.graheli@gmail.com 
two major reasons. First, critical editions rarely cover the full span of works, except for very short ones, so the documentation justifiably embraces only manuscripts relevant to the portion that is about to be edited. Second, introductions of critical editions are often quite bulky, since they need to convey a great amount of information related to the applied method, to the historical background, to the genealogy of the transmission, etc.; therefore, a documentation of not directly relevant manuscript sources is generally left out for pragmatic reasons, and the precious ground-work done by zealous editors risks to be left unpublished. Yet, a wide dissemination of the inventorial research done in preparation of sound editions is certainly desirable and contributes to the growth of the discipline by saving the time and energy of specialists, who can thus easily locate the needed manuscript sources. In classical studies the separate publication of such inventories is well established in the form of "special catalogues", which can be catalogues of manuscripts of a single work, author, discipline, tradition, epoch, genre, etc. ${ }^{2}$

The following list of NM manuscripts is of course not conclusive, since it is very likely that more NM manuscripts will be discovered in the enormous quantity of not yet surveyed manuscript material in South Asia. As for the published catalogues, however, it is intended as fairly exhaustive. It was gradually built through the following progressive steps:

1. consultation of the catalogi catalogorum;

2. consultation of individual catalogues;

3. consultation of published and unpublished hand-lists, indexes, and registers;

4. identification of the manuscripts used in printed editions in the above mentioned catalogues;

5. integration of manuscripts information gathered from colleagues.

One should keep in mind that when compilers of the Catalogus Catalogorum (CC) and the New Catalogus Catalogorum (NCC) gathered entries of a given work that was detected in more than one catalogue, they did not necessarily check whether such entries referred to one or more physical manuscripts, as it will be seen below in some cases of NM records. A single manuscript, indeed, may have been recorded again in a new catalogue, for instance after a library reshuffle, under a different number; or, it may have been shifted from or to a different collection or library, and thus be recorded in other hand-lists or catalogues under an altogether different identifier. Also, the information about authors and works found in catalogues often needs to be taken with a grain of salt, since general catalogues cannot be specialized in every genre and mistakes are always a distinct possibility. Since a catalogus catalogorum is a meta-catalogue containing mostly second-hand information, such errors can be reproduced along with new potential errors. To assess the reliability of the information, it is therefore important to unravel the information from catalogi catalogorum by reconstructing the path synthesized in their records, and gather all the available data about published and unpublished inventories, lists and catalogues. In the best scenarios, one could even trace back a

\footnotetext{
${ }^{2}$ On possible types of special catalogues, see Petrucci (2001, pp. 117-119). A well-known example of special catalogue is Shullian (1981).
} 
detailed description of the manuscript contained in a descriptive catalogue, where decisive pieces of evidence such as an incipit or a colophon could be provided. For all this purposes, the amount of information found in the bibliographies of catalogues done by Janert $(\mathrm{ABC})$ and Biswas $(\mathrm{BBC})$ cannot be overestimated. Without these works, the interpretation of many forgotten names of lists and catalogues mentioned in $\mathrm{CC}$ and NCC would be extremely difficult, if not impossible.

\section{A Preliminary List of NM Manuscripts}

\subsection{Catalogus Catalogorum Records}

Aufrecht registered three NM entries (CC, vol. 1, p. 309):

- Ph 13

- Report XXV (see description below, BORI 390/1875-76) ${ }^{3}$

- Rā 13.14

According to the legenda in CC, vol. 1, Introduction, p. v, Ph 13 refers to the "Pheariçt [pheharist] Saṃskrita ke Pustakon kā [Hindi, "List of Sanskrit Manuscripts"] 16 pages in 8". Biswas (BBC, p. 220) located this list at the University of Madras, Department of Sanskrit. Nothing more is known about this entry.

Rā 13.14 refers to the "Pustakānāṃ Sūcipatram, 48 pages in 8", a list referring to the collection of Paṇịit Rādhākrṣna of Lahore. The list was compiled by the Kāśmīrī paṇ̣it named Rājarāma Śāstrī, as for the colophon at the end: likhitam paṇụtarājarāmaśāstriṇā kāśmīrivāsinā. Biswas (BBC, p. 237) mentions this collection under Rājarāma Śāstrī’s name, without specifying Rādhākṛṣna’s, while Janert (ABC, p. 144) reports the bare information from the CC. The printed list of the Rādhākṛ̦na collection, a copy of which is preserved in Tübingen, records the NM manuscript at p. 13, no. 119. The list is also available in Berlin and London (India Office). It was likely compiled or printed in 1871 or before, according to a hand-written note present in the first page of the Tübingen copy. The number 13 in the CC entry may refer to p. 13 of this Sūcipatra.

Report XXV refers to Cat. Report 1875, p. XXV, where the manuscript purchased in 1875 by Georg Bühler is described. Bühler was appointed by the Bombay Presidency of the British Government to search for Sanskrit manuscripts in areas of central and northern India. In his Report this manuscript is listed with the catalogue no. 390 (see description below, BORI 390/1875-76).

\subsection{New Catalogus Catalogorum Records}

The NCC (NCC10, p. 256) records the entries of NM manuscripts as follows:

\footnotetext{
3 The sigla in bold typeface are used in this paper as identifiers for cross-reference purposes. In each siglum, an acronym of the last known repository is followed by the manuscript number of the library, in this case Bhandarkar Oriental Research Institute, manuscript no. 390/1875-76.
} 
Adyar II. p. 98a. Adyar D. VIII 463. BORI. 390 of 1875-76. Luck. Uni. p. 40. Mad. Uni. R. K. S. 543. Mt. 3631 (a) (inc.). Mysore I. p. 392. Report XXV. Skt. Coll. Ben. 1897-1901, p. 14 (no. 50).

This piece of information needs to be disentangled, first of all according to the bibliographical information on catalogues given in the Abbreviations, NCC1, VIIIXXIX and in their revised version (NCC Abbreviations). As it is often the case with catalogi catalogorum entries, manuscripts are registered more than once under different labels:

- Adyar II. p. 98a. This entry refers to Cat. AL 1928, p. 98 (cf. NCC1, p. i; ABC, p. 93; BBC, p. 155). In the catalogue, the manuscript is listed as " $24 \mathrm{C} 16$ ke 280 (atiśithilā ["very brittle"])". According to Cat. AL 1926, vi-viii, 24 stands for the shelf, $\mathrm{C}$ for the row, and 16 for the manuscript number; ke stands for Kerala, Malayālam [script], and 280 is the number of pages of the manuscript (see description below, AL 70179b).

- Adyar D. VIII 463. This is most likely not a NM manuscript, but rather a Nyāyasiddhāntamañjarī one: although listed as Nyāyamañjari, in Cat. AL 1928, p. 115, it is attributed to Jānakīnātha and not to Jayanta. That it is Jānakīnātha's work is also confirmed in the concordance given in the appendix of Cat. AL 1972, p. 548.

- BORI. 390 of 1875-76. The 1875-76 BORI collection refers to the manuscripts purchased by Georg Bühler on behalf of the Bombay Presidency in those years (cf. ABC, p. 126; BBC, pp. 226-227). It corresponds to Report XXV in the Catalogus Catalogorum (CC) above (see description below, BORI 390/187576).

- Luck. Uni. p. 40 (LU 45440). This manuscript is catalogued in Cat. LU 1951, p. 40 (cf. ABC, p. 90; BBC, p. 153): Serial No.: 132; Call No.: 181-412 J35; Author: Jayanta Bhatta [sic]; Title: Nyāyamañjarī; Accession No.: 45440.

- Mad. Uni. R. K. S. 543 (MU RKS 543). In the original edition of NCC (1949), p. xxi, the "Mad. Uni. R. K. S." siglum is described as "[A] hand-list of 577 Sanskrit manuscripts of the late R. Krishnasvami Sastri, Sub Registrar, Tanjore, acquired for the Madras University by R. A. Sastri." The revised edition, NCC1, p. xiii, adds "[I]n the Sanskrit Department, University of Madras". The list is still unpublished (BBC, p. 178).

- Mt. 3631(a) (inc.) (GOML R. 3631a). "A Triennial Catalogue of Manuscripts [...]” Cat. GOML 1927, p. 5369 (cf. NCC1, p. xiv; ABC, p. 98; BBC, p. 163). The number 3631 is the serial number of the Triennial catalogue (see description below, GOML R. 3631a).

- Mysore I. p. 392. This manuscript is listed in Cat. GOL 1922, p. 392 (cf. NCC1, p. xiv; BBC, p. 187) (see description below, ORI C-1374).

- Report XXV. Same as BORI 390 and Report XXV above (see description below, BORI 390/1875-76).

- Skt. Coll. Ben. 1897-1901, p. 14, no. 50. The NCC reference is to Cat. SC 1902, p. 14, no. 50. In Cat. SBhL 1962 the same manuscript is listed under serial no. 33668, repeating the same access no., i.e. 3465 (see description below, SSV 3465). 


\subsection{Further Catalogued NM Manuscripts}

The following are additional manuscripts of the NM listed in individual catalogues, but not in the CC or NCC.

- (GJ 833/52) Ms. no. 833/52, preserved at the Rashtriya Sanskrit Sansthan, Ganganath Jha Campus, formerly Ganganath Jha Kendriya Sanskrit Vidyapeetha and Ganganath Jha Research Institute, Allahabad (Cat. GJRI 1967, 548549).

- (NSUB MU II 26) Ms. Mu II 26, preserved at the Niedersächsische Staats-und Universitätsbibliothek, Göttingen (Cat. VOHD 1970, p. 228).

- (NSUB MU I 95) Ms. Mu I 95, preserved at the Niedersächsische Staats-und Universitätsbibliothek, Göttingen (Cat. VOHD 1970, p. 229).

- (AS G-10991) Ms. no. G/10991, preserved at the Asiatic Society, Kolkata (Cat. AS 1957, pp. 105-108).

- (ABhSP 2381) Ms. no. 2381, preserved at the Akhila Bharatiya Sanskrit Parishad, Lucknow (Cat. LA 1970, p. 345).

- (GOML R. 3583) A manuscript in the Government Oriental Library, Madras. S. no. 5803, a. no. R. 3583 (Cat. GOML 1938, p. 217). An additional number, S. R. 1712, is also given in the microfilmed page containing the manuscript information. The number 3583 is the serial number from Cat. GOML 1927, p. 5321. In the microfilmed copy of the catalogue page available to me, the number of the microfilm reel, 1136, is also added by hand. The number 5803 is the serial number in Cat. GOML 1938, p. 217.

- (ORL 1088) Ms. no. 1088, preserved at the Oriental Research Library, University of Kashmir, Srinagar (Cat. SORL 1989, p. 94).

- (ORL 1933) Ms. no. 1933, preserved at the Oriental Research Library, University of Kashmir, Srinagar (Cat. SORL 1989, p. 94).

- (ORL 2179) Ms. no. 2179, preserved at the Oriental Research Library, University of Kashmir, Srinagar (Cat. SORL 1989, p. 94).

- (BHU C-1015) Ms. no. C1015, preserved at the Central Library, Banaras Hindu University, Varanasi.

- (BHU C-4666) Ms. no. C4666, preserved at the Central Library, Banaras Hindu University, Varanasi. ${ }^{4}$

I also came across some further NM catalogue entries that most likely refer to the Nyāyasiddhāntamañjari and erroneously mention Jayanta as the author, as it is the case with Adyar D. VIII 463 in the NCC, listed above. For instance, at the Osmania University Library in Hyderabad, there is a record of four "Nyāyasiddhāntamañjarī, also called Nyāyamañjarı̄” manuscripts ascribed to Jayanta, one in Telugu script (17th c.), complete and damaged, and three in Devanāgarī script (18th c.), fragmentary (Cat. OUH 1964, pp. 160-161). These, however, are most likely references to Jānakinātha's later work, since the extant parts are described in the catalogue

\footnotetext{
${ }^{4}$ For BHU C-1015 and BHU C-4666, I could not yet consult the catalogue of the Library, Cat. BHU 1971.
} 
according to the division of the Nyāyasiddhāntamañjarī (pratyakșaparicchedah, etc.), and not according to those of the NM (prathamam ähnikam, etc.).

\subsection{Further Non-Catalogued NM Manuscripts}

Three further NM manuscripts came to my attention through the personal communication with colleagues, and to date I could not find any printed catalogue or list mentioning or describing them.

- (DC 10663) Ms. no. 10663, preserved at the Deccan College, Pune.

- (AA 5329) Ms. no. 5329, preserved at the Anandashram, Pune.

- (MDUC 2606) Ms. no. 2606, preserved at the Malayalam Department of the University of Calicut.

In conclusion, among the NM entries in CC and NCC there are still three manuscripts, MU RKS 543, Ph 13 and Rā 13.14, whose identity or location remains unclear. Light on MU RKS 543 may be shed by the staff at the University Library in Madras. As for $\mathbf{P h} 13$ and $\mathbf{R a} \mathbf{1 3 . 1 4}$, one possible source for further clarification could be some additional record at the NCC Office in Madras.

\section{Description of the NM Manuscripts}

In the following I will supply a concise external description, an outline of their extent, and some historical information about these manuscripts, derived from the direct examination of their photographs, microfilms, or photocopies, as well as from the descriptions given in catalogues. Copies of one manuscript (ABhSP 2381) were not available to me, so in its case the description is based on the information from the catalogue and on the collation by Kei Kataoka (see KKc and KKd).

The manuscripts are alphabetically ordered according to the place where the manuscript is presently located. The headings mention the city and the last known repository. The abbreviated form with number, used in this paper for cross referencing purpose, is repeated in parentheses at the end of the heading.

The external description of the manuscripts, in smaller typeface, mentions in order all or some of the following: date of the manuscript, available only in two cases $^{5}$; number of leaves; size of leaves in millimeters (height $\times$ width); support (paper, birch-bark, palm-leaf); script. Lastly, the nature of the consulted copy (photocopy, digital photographs, microfilm) is also mentioned.

\footnotetext{
5 Only two of the 18 described manuscripts are dated, BORI 390/1875-76 and SSV 3465, respectively Śāka 1394 (CE 1472) and Samvat 1794 (CE 1736-1737), so the earliest extant manuscript was written about five centuries after the composition of the NM. Bhatta Jayanta wrote the NM between the last quarter of the 9th century and the beginning of the 10th. For evidence about the date and other biographical information, see Frauwallner (1936, pp. 267-268); Hacker (1951); Oberhammer (1962, p. 146); Gupta (1963, pp. 9-12); Matilal (1977, pp. 92-94); Potter (1995, pp. 345-346); Slaje (1986, p. 245 et passim); Dezső (2005, Introduction); Kataoka (2007b); Slaje (2012).
} 
The extent of the manuscripts has been determined as carefully as possible. Incipit and explicit of the whole text in the case of complete manuscripts, and of major portions of text in the case of incomplete ones, are provided to give possible clues about the scribe's personality, and to facilitate a precise assessment of the missing parts. In the case of the only two dated manuscripts, the extract of the colophon is separately quoted. Extracts are not strictly diplomatic: obvious errors have been occasionally corrected. Punctuation marks specific of script (dots, half danḍas, etc.) are all rendered as slashes.

Miscellaneous notes, including historical information, and bibliographical references close the descriptions.

2.1 Allahabad, Rashtriya Sanskrit Sansthan, Ganganath Jha Campus, Formerly Ganganath Jha Research Institute (GJ 833/52)

668; $105 \times$ 275; paper; Devanāgarī; photocopies.

Contents: Contains the complete text. Foll. 1-668 in the original foliation, with occasional repetition and eye-skips or repetitions of foliation.

Incipit: [1v1] śrīgaṇeśāya namah om namah śáśvatikānamiajñānaiśvaryamayātmane [...] (KSV I 1,1).

Explicit: [668v7-8] [...] prapannajanasaṃalpavṛsṣāya śambhave // iti śrījayaṃtabhațtakrtāyām nyāyamamjaryyām dvādaśam āhnikam / samāptā ceyam nyāyamaṃarī śubham // (KSV II 718,9-12).

Notes: It was used in the two volumes of the Mysore edition. In KSV, vol. I, its variants are listed in the appendix, since the manuscript was obtained only after the completion of the apparatus. In KSV, vol. II, it is collated in the apparatus with the siglum ca (KSV, vol. I, Prastāvanā, p. ii). It is a direct copy of ORI C-1374 above, at least as far as NM 6 is concerned, ${ }^{6}$ as evident to me after a thorough stemmatic analysis of that $\bar{a} h n i k a .^{7}$ This fact seems to have escaped the attention of Varadācārya, who collated both manuscripts in his edition.

Bibliography: Cat. GJRI 1967, p. 549; KKa, p. 118; KKb, p. 135; KKc, p. 60; KKd, p. 129.

\subsection{Chennai, Adyar Library (AL 70179b)}

142; $60 \times 480$; palm-leaf; Malayālam; digital photographs.

\footnotetext{
${ }^{6}$ Kataoka, after studying the beginning of NM 5, reaches a different conclusion, i.e. that the two manuscripts derive from a common exemplar (see KKh, pp. 11-13).

7 A critical edition of NM 6, based on the collation of all the available manuscripts and a thorough stemmatic analysis is presently in its final editing process and will soon be published.
} 
Contents: NM 1-5 are lost. Contains NM 6-12, but with several missing folios and the serious damage on most leaves. In the original foliation, written in letter numerals of the alphabetical variety (see Grünendahl 2001, p. xiv), NM 6 began probably on folio $k a^{8}$ and ends at jhau; foll. $k a$ and $k \bar{a}$ are missing, and the extant part begins from $k i$. Perhaps $k a$ was empty, used as cover, or the manuscript began from the recto side, according to the missing amount of NM 6 text at the beginning.

Incipit: $\quad[3 \mathrm{r} 1(\mathrm{ki})]$-ntanīyah avyatireke ta eva te varnā iti kathan na bodhakā [...] (KSV II 147,7).

Explicit: $\quad$ [142v6 (jhau)] (KSV II 718,10).

Notes: The first catalogue record of this manuscript is found in Cat. AL 1911 , p. 182, where it is mentioned without manuscript number as follows: "Nyāyamañjarī by Jayantabhaț̣a; No. of copies: 1; Character: Malayālam". It is then mentioned in Cat. AL 1928, p. 98 as " 24 C 16 ke 280 (atiśithilāa)", i.e. shelf 24, row C, ms. no. 16 , leaves 280 , very brittle. The manuscript number given in the new Adyar catalogue is different (Cat. AL 1972, 82-83): Acc. No. 70179(b); however, the number of folios given in the two catalogues $(140=280$ pages $)$ and the mention of the brittle state suggest that it is the same manuscript, and that it was already mutilated back in 1911. The manuscript is collated in KSV (see KSV, vol. II, Bhümikā, p. viii), with the siglum gha. The extent of the manuscript (missing the first five ähnikas) and the direct evidence encountered throughout my collation of NM 6 confirm this identity. The Malayālam script presents features of the Grantha of the Eastern variety described in Burnell (1878, p. 41). From the digital photographs it appears extremely brittle. It is severely damaged, with loss of material throughout; several leaves have eroded margins, fragmented parts and mutilated halves; occasionally there are fading portions of text.

Bibliography: Cat. AL 1911, p. 182; Cat. AL 1972, pp. 82-83; KSV, vol. II, Bhūmikā, p. viii.

\footnotetext{
8 According to Grünendahl (2001, p. xiv), before $k a$ there would be 55 numbers, but this does not work in this case: from $k a$ to jhau there are factually nine vargas $(k a$ to $j h a): 9 \times 16=144,-2$ (jhah and $j$ ham $)=142$. There are 142 leaves that cover NM 6-12. Four leaves are missing in NM 8-9. So 55 leaves would not be sufficient to cover NM 1 to NM 5, which at the ratio of the second part should employ about 176 leaves. It is therefore more likely that the count of the first, missing part of the NM in this case started from $k a$, and not from the vowels as in the case of the samples examined by Grünendahl, and it was started anew beginning with NM 6 (cf. also the partitions in BORI 390/1875-76 and in BHU C-1015).
} 


\subsection{Chennai, Government Oriental Manuscripts Library (GOML R. 3583)}

129 (Cat. GOML 1927, p. 5321); $396 \times 44 \mathrm{~mm}(155 / 8 \times 13 / 4$ inches, see Cat. GOML 1927, p. 5321); palm-leaf; Malayālam; digital photographs.

Extent: $\quad$ Contains fragmentary parts of NM 7-12.

Notes: Information from Cat. GOML 1927, p. 5321: "R. No. 3583. Śrītāla. $155 / 8 \times 13 / 4$ inches. Foll. 129. Lines, 9 in a page. Malayālam. Slightly injured. Purchased in 1920-1921 from M. R. Ry. ${ }^{9}$ Payyūr Nīlakaṇtha Patteri, Kunnankulam post, Cochin State. Gautamasūtratātparyavivrtiḥ: Nyāyamañjarī. Fol. 129 is left blank. A learned amplification of certain aphorisms of the Nyāyadarśana. This work has been published as No. 10 in the Vizianagram Sanskrit Series. By Jayantabhatța. Contains the Āhnikas 7-11 complete and Āhnika 12 incomplete, but wants the beginning in the seventh Āhnika. Beginning: uta dve ete smrtyanubhavajñāne / [...]". Information from Cat. GOML 1938, p. 217: "Serial No.: 5803; Name of the work in Sanskrit: Gautamasūtratātparyavivṛtiḥ Nyāyamañjarī; Name of the Author: Jayantabhațta; Subject matter: Nyāya; Substance: Palmleaf; Character: Malayālam; Extent: Incomplete; Reference to the Des. or Tri. Catalogue or Shelf number: R. 3583”. Information from microfilm label: "Record No: 17823; Roll No: 1136; Date of filming: 24-7-96; Bundle No: S. R. 1712; Triennial catalogue volume: 3583, IV-I-B; Author: Jayantabhaț̣a; Title: Gautamasūtratātparyavivṛtị Nyāyamañjarī; Subject: Nyāya; Language: Sanskrit; Script: Malayālam; No. of Folios-Pages: 130 (Fol. 1a-130b); Incomplete; Remarks: Brittle, Injured". The manuscript is perhaps the one collated in KSV (see KSV, vol. II, Bhümikā, p. viii), with the siglum $\dot{n} a$.

Bibliography: Cat. GOML 1927, p. 5321; Cat. GOML 1938, p. 217; KSV, vol. II, p. viii.

\subsection{Chennai, Government Oriental Manuscripts Library (GOML R. 3631a)}

89 (Cat. GOML 1927, p. 5369); $375 \times 44$ (14 3/4 × 1 3/4 inches, see Cat. GOML 1927, p. 5321); palmleaf; Malayālam; microfilm.

Extent: $\quad$ Contains fragmentary parts of NM 7-12.

\footnotetext{
9 M. R. Ry. is an abbreviation of Mahārājarājaśrī, according to Grünendahl (2001, p. 52).
} 
Notes: $\quad$ Information from Cat. GOML 1927, p. 5369: "R. No. 3631. Śn̄tāla. 14 $3 / 4 \times 13 / 4$ inches. Foll. 89. Lines, 8 in a page. Malayalam. Much injured. Purchased in 1920-1921 from M.R.Ry. Payyūr Nīlakaṇṭha Pațteri, Kunnankulam post, Cochin State. Nyāyamañjarī: Gautamasūtratātparyavivrtị. Foll. 1a-26b. [...] Contains the 12th Âhnika complete, but wants the beginning and the leaves are in disorder. End: [...] prapannajanasan்kalpakalpavrkșāya śambhave // Colophon: iti śrībhațtajayantasyakrtau nyāyamañjaryām dvādaśam āhnikam // samāpta ceyam nyāyamañjar $\vec{\imath}$. Information from Cat. GOML 1938, p. 218: "Serial No.: 5804; Name of the work in Sanskrit: Gautamasūtratātparyavivrtị̆ Nyāyamañjarī; Name of the Author: Jayantabhața; Subject matter: Nyāya; Substance: Palm-leaf; Character: Malayālam; Extent: Incomplete; Reference to the Des or Tri Catalogue or Shelf number: R. 3631(a)". Information from a manuscript label, on a fly-leaf: "Nyāyamañjarī, SR. 1760, R. 3631". The number "SR. 1760" is provided also on a sticker on the wooden cover. It is possible that GOML R. 3631a and GOML R. 3583 are fragmented parts of what was originally a single manuscript and so far, indeed, I could not detect any overlapping parts that would falsify this hypothesis.

Bibliography: Cat. GOML 1938, p. 218; KKa, p. 118.

2.5 Göttingen, Niedersächsische Staats-und Universitätsbibliothek (NSUB MU II 26)

18; 215 × 140; paper; Sāradā; microfilm.

Extent: Contains about one third of NM 1. Foll. 1-18 in the original foliation.

Incipit: $\quad$ svasti / om namo gaṇapataye / om șrīśāadācaraṇakamalebhyo namaḥ / om namaḥ śrīparameśvarāya kșityādikartre / om namah śrīmahātripurasundaryai // om namaḥ śāśvatikānandajñānaiśvaryamayātmane [...] (KSV I 1,1).

Explicit: $\quad$ [..] kriyāsv abhāvatvāt tasya parokṣam tad ayuktam na [18r20] (KSV I 45,5).

Notes: Contains marginalia related to Cakradhara's Nyāyamañjarīgranthibhanga (see Muroya 2009-2010, pp. 226-228).

Bibliography: Cat. VOHD 1970, p. 228; KKd, p. 129; Muroya (2009-2010, pp. 226-228).

2.6 Göttingen, Niedersächsische Staats-und Universitätsbibliothek (NSUB MU I 95)

15; $245 \times 175$; paper; Śāradā; microfilm.

Contents: Contains about half of NM 1. Foll. 1-15 in the original foliation. 
Incipit: [1v1-2] om svasti śrīgaṇeśāya sarvavignadhvamsine namah // om namo viṣnave om namaḥ śāśvatikānandajñānaiśvaryamayātmane [...] (KSV I 1,1).

Explicit: $\quad$ [..] adhigatam artham adhigamayatā pramānena piștam piștam syād iti [15v27] (KSV I 80,8).

Notes: Contains marginalia related to Cakradhara's Nyāyamañjarīgranthibhañga (see Muroya 2009-2010, pp. 226-228).

Bibliography: Cat. VOHD 1970, p. 229; KKd, p. 129; Muroya (2009-2010, pp. 226-228).

\subsection{Kolkata, Library of the Asiatic Society (AS G-10991)}

375; $150 \times 320$; paper; Devanāgarī; microfilm.

Extent: $\quad$ Contains NM 1-10. Foll. 1-375 in the original foliation.

Incipit: [1r1] om śrīganeśāya namah om namah śivāya gurave // om namah śāśvatikānamiajñānaiśvaryamayātmane [...] (KSV I 1,1).

Explicit: $\quad$ [..] prāyaih̆ śakyo na pakșah kṣapa[375v]yitum iti hi vyāharad vrttikāraḥ avayavapadārthaḥ // bhațtajayamtakrtau nyāyamamjaryàm daśamam āhnikam samāptam // (KSV II 583,4-6).

Notes: $\quad$ There are marginalia with passages from the GBh (see Muroya 2009-2010, p. 226).

Bibliography: Cat. AS 1957, 105-108; Muroya (2009-2010, p. 226).

\subsection{Lucknow, Akhila Bharatiya Sanskrit Parishad (ABhSP 2381)}

138; 283 × 205; paper; Śāradā; copies not available.

Extent: $\quad$ NM 1-3 and part of NM 4. Foll. 1-138 in the original foliation.

Incipit: $\quad$ svasti om namah sarasvatyai śrīśāradāyai namaḥ om śrīganēśāya namaḥ śreyase om namaḥ śāśvatikānandajñānaiśvarye mayātmane [...] (KSV I 1,1; see KKd, p. 139).

Explicit: $\quad$ [...] vatsah prcchati (KSV I 630,1; see KKb, p. 139).

Notes: It was donated to the ABhSP by Paṇdit Vidyeśvaranātha Rājadāna, a Lucknow resident. Worm-eaten" (Cat. LA 1970, p. 345).

Bibliography: Cat. LA 1970, p. 345; KKb, p. 135; KKc, p. 61; KKd, p. 130.

2.9 Mysore, Oriental Research Institute (ORI C-1374)

392; $155 \times 330$; paper; Devanāgarī; digital photographs.

Extent: $\quad$ Contains the complete text. Foll. 1-291 in the original foliation.

Incipit: [1v1] om śrīgaṇeśāya namaḥ om śrīsārikābhagavatyai om śrīgurucaraṇakamalaparāgapunyebhyo namah om namaḥ śáśvatikānamdajñānaiśvaryamayātmane [...] (KSV I 1,1). 
Explicit: [291v13]-kuraśriye prapannajanasaṃalpakalpavṛsșāya śambhave // iti śrījayamtabhațtakrtāyām nyāyamamjaryyām dvādaśam āhnikam samā[291v14]ptā ceyam nyāyamamjarī śubham (KSV II 718,10-12).

Notes: It was used in the two volumes of the Mysore edition, with the siglum ka. See KSV, vol. I, Prastāvanā, p. ii, where the editor describes it as "a paper manuscript situated at the [Mysore] Research Library" (etatsamísodhanālayasthah kāgadapatrātmakah kośah [...]), without a more precise identification; my collation of NM 6 confirms the identity.

Bibliography: Cat. GOL 1922, p. 392; KKh, p. 11.

2.10 Pune, Anandashram Sanstha (AA 5329)

64; $155 \times 330$; paper; Devanāgarī; photocopies.

Extent: Contains parts of NM 5-7. Foll. 238-247 + 250-303 in the original foliation. It begins with the last third of NM 5, continues with the full NM 6, save for the first three folios and for fol. 265, and ends with the beginning of NM 7.

Incipit: [204r1] -stīti tataś ca hananasya [...] (NM5, KSV II 112,12).

Explicit: [303v11] praveśạ krśānor anumīyate tena vegavatā vahnidravyena nodanād abhighātād vā nūnam ghațādyarambhakeșv avayaveșu kriyā (KSV II 286,8).

Notes: The extent, calligraphy, and format of AA 5329 coincide exactly with those of the displaced part of NM 5-7 missing in DC 10663 below. The photocopies were obtained by Takuya Ono on 4.3.2004.

\subsection{Pune, Bhandarkar Oriental Research Institute (BORI 390/1875-76)}

Śāka 1394 [CE 1472]; 432; 130 × 130; birch-bark, bound; Śāradā; digital photographs.

Extent: The manuscript is presently constituted of 432 leaves (435 according to Cat. Report 1875, p. XXV). The original foliation runs up to NM 3 and restarts from NM 4: 3-149 (= NM 1-3) + 1-270 (= NM 4-12) + 282-286 (an unidentified work) + 7 (parts of Raghuvamśa 15.11-78). Except for occasional missing leaves, the NM is complete. The first two folios are lost.

Incipit: [3r1] -lāviharanodyataih [...] (KSV I 3,9).

Explicit: [..] prapannajanasañkalpakalpavṛkṣāya śambhave // [270v17] (KSV II 718,10). 
Colophon: [270v18] ity ācāryārjunasvāmiputraśitikanțasvāmilikhitāyām bhațtajayantasya krtau nyāyamamjaryām dvādaśam āhnikam // samāptā ce [19]yam nyāyamaṃjarī // śișyān adhyāpayitum śitikaṇthasvāminā guruṇa $[(271) r 1]$ gautamamatatattvavidā(tva)ritam śrīnyāyamañjarī likhitā // om namaś śrì [2]śāradāyai // om namo mahāganapataye // iti śubham astu lekha[3]kapāthakayoḥ // śāke 1394 āśva śuti 10 //

Notes: The manuscript was written in Kaśmīra in śāka 1394 (1472 CE). ${ }^{10}$ It is signed by Ācārya Śitikaṇțha Svāmī, son of Arjuna Svāmī. Ācārya Śitikantha was also the author of a commentary (Nyāsa) of Jagaddhara's (14th c.) grammatical work Kätantrabālabodhinī (see Coward and Kunjunni Raja 2001, p. 486 and NCC 3, p. 317), as confirmed by the identical form of the signature in a Nyāsa manuscript listed in VOHD 6219 (2.17, p. 111), ity ācāryārjunasvāmiputraśitikanțasvāmi..., as well as by the date, which in VOHD 6219 is Śāka 1393, the year before the date of BORI 390/ 1875-76. In the digital photographs seen by me (taken between 2004 and 2007), several leaves are damaged, with missing fragments and peeled-off areas; most leaves had been framed with a white ribbon, probably to contain the typical birch-bark deterioration. The ribbon occasionally hides lines or parts of lines, marginalia, and foliation. $^{11}$

Bibliography: Cat. Report 1875, p. XXV; Cat. DC 1888, p. 95; GDh, Bhūmikā, p. 5; Muroya (2009-2010, pp. 27-29).

\subsection{Pune, Deccan College (DC 10663)}

254; $155 \times 330$; paper; Devanāgarī; photocopies.

Extent: $\quad$ Contains NM 1-4, part of NM 5, and part of NM 7 (see AA 5329 above). Foll. $1-195+204-237+303-327$ in the original foliation. NM 1-4 are almost complete, except for 4-5 leaves missing at the end of NM 4. NM 5 has a gap of about five leaves at the beginning and lacks about one third of the āhnika at the end. NM 7 lacks the first nine leaves (foll. 295303) and is otherwise complete.

Incipit: [1v1] om svasty astu // śrīgaṇeśāya namaḥ // namaḥ śāsvatikānāmịdajñ̄ānaiśvaryamayātmane [...] (KSV I 1,1).

\footnotetext{
${ }^{10}$ According to the year, month, and lunar day given in the colophon, the manuscript was completed on Saturday, September 12, 1472, as calculated by the on-line pañcānga of Michio Yano (www.cc. kyotosu.ac.jp/yanom/pancanga/index.html).

11 For more details about Ācārya Śitikaṇtha and his works, see Sanderson (2007, p. 301) and Muroya (2009-2010, pp. 27-29).
} 
Explicit: [327v4] -pacitaparinamatkarmapākopanītam duḥkham saṃtyajya niḥśreyasam akhilatayānitam āptum yateta // iti śrījabhațtajayam [327v5] takṛtau nyāyamaṃjaryāṃ saptamam āhnikam // (KSVII 359,7-9).

Notes: I could not find any catalogue or other bibliographical reference. The flyleaf of the manuscript reads "Nyāyamañjarī I First 7 Ahnikas I Acc. No. $10663 \mid$ Deccan College $\mid$ Pune $|33 \times 15.5 \mathrm{~cm}|$ Line $=11 \mid$ Folios $=372 \mathrm{c} \mid$ Letters 45". The missing portion coincides with AA 5329 above.

\subsection{Srinagar, Oriental Research Library (ORL 1088)}

167; $150 \times 240$; paper; Śāradā; digital photographs.

Extent: $\quad$ Contains NM 1-4, foll. 2-189 in the original foliation, and one stray folio of NM 8 (KSV II 364,9-369,8). As for NM 1-4, the first folio is missing, the missing portion corresponding to the verso of the first folio, and NM 4 is incomplete.

Incipit: $\quad$ [2r1] guṇaih santah prahrṣyanti citram eșām viceștitam [...] (KSV I $4,6)$.

Explicit: $\quad$ [...] kūtasyānityatve pravāha [189v16] (KSV I 641,7).

Bibliography: Cat. SORL 1989, p. 94.

\subsection{Srinagar, Oriental Research Library (ORL 1933)}

99; $150 \times 240$; paper; Śāradā; digital photographs.

Extent: $\quad$ Contains part of NM 5-8. NM 5 lacks a few folios at the beginning. NM 6-7 are complete, save for occasional missing folios, and NM 8 is incomplete, lacking about one fourth of the ähnika. Foll. 210-309 in the original foliation. ${ }^{12}$

Incipit: [210r1] kalpitam tu tat vaktum aśakyam kalpanayaiva [...] (KSVII 20,12).

Explicit: $\quad$ [...] iti coditam parihṛtam tad bhāṣyakāreṇa [309v16] (KSV II 405,14).

Notes: $\quad$ There are frequent changes of hand. The chapter-endings with Sitikaṇtha's signature (see BORI 390/1875-76 above) have been occasionally copied at the end of āhnikas and later crossed out. This shows that BORI 390/1875-76 was an ancestor of ORL 1933, at least for some of its parts.

Bibliography: Cat. SORL 1989, p. 94; KKf, pp. 18-19.

\footnotetext{
12 According to Kataoka (KKf, p. 19), the manuscript is constituted of 98 leaves, while I counted 99 of them. Also, the text edited by him is contained in foll. 200-202, which I failed to detect in the photographs seen by me.
} 


\subsection{Srinagar, Oriental Research Library (ORL 2179)}

68; $150 \times 240$; paper; Śāradā; digital photographs.

Extent: $\quad$ Contains NM 3-4. NM 3 lacks the first leaf. NM 4 is incomplete. Foll. 2-65 in the original foliation. Contains also three stray folios of NM 1, foll. 6-8 in the original foliation, corresponding to KSV I 28,8-43,7-8.

Incipit: $\quad$ upadeśatvaprasangah śabde ca [...] (KSV I 398,9).

Explicit: $\quad[.$.$] yat tu trikālānavacchinnah katham pratyakșa- (KSV I 633,1).$ Bibliography: Cat. SORL 1989, p. 94.

2.16 Thenjipalam (Malappuram District), Malayalam Department of the University of Calicut (MDUC 2606)

188; ca. $50 \times 480$ (inferred from photographs); palm-leaf; Malayālam; digital photographs.

Contents: $\quad$ Contains the complete NM 1-6 and about one third of NM 7. In the original foliation, the first leaf is foliated as $s r \bar{l}$, and is followed by foll. $1-187$ in letter numerals $(1=n a-187=\tilde{n} a$-cha-gra $)$ (see Grünendahl 2001, p. 94).

Incipit: [1r1]hariḥ om mahāgaṇapataye namaḥ namaś śāśvatikānandajñānaiśvaryamayātmane [...] (KSV I 1,1).

Explicit: $\quad$ [..] kim sa evāyam stambha ity ekam jūāna- [187v10] (KSV II $308,10)$.

Notes: $\quad$ The manuscript is listed in a register of the Library, p. 156, as No. 2606, Nyāyamañjarī - Nyāyasutravyākhya. At p. 14 of another list, a collection of 191 manuscripts (2603-2793), to which MDUC 2606 belongs, is mentioned along with the previous owner, Sri K. V. Ravinamputhiripadu, Killimangalathu Mana, Killimangalam P. O, Cheruthuruthy (Thrissur District). ${ }^{13}$ The same manuscript is identified by Kataoka (e.g. KKh, p. 11) with the number 2602.

Bibliography: KKb, p. 135; KKc, p. 60; KKd, p. 129; KKe, p. 6; KKh, p. 11.

\subsection{Varanasi, Banaras Hindu University (BHU C-1015)}

114; $202 \times 350$; paper; Devanāgarī; digital photographs.

\footnotetext{
13 The Department of Sanskrit of the University of Calicut (founded in 1969) was created in 1977, and the Department of Malayalam in 1971. The latter, according to the website (http://www.university ofcalicut.info, consulted in January 2012), takes care of the collection of manuscripts, called Thunchan Manuscript Repository.
} 
Extent: $\quad$ Contains NM 1-4, the very beginning of NM 5, and part of NM 8-9. Foll. I. 1-83 + II. 50-79 in the original bipartite foliation. NM 1-4 is complete. Only the first and half folios of NM5 are preserved, ending with [83v23] -yādiṣv asti // athavā // śāvaleyādisvalakṣasamudāyam [...] so py aghatamāna eva samudāyivyatirekeña tasyānu- (KSV II 15,9-11). The last third of NM8 and the complete NM 9-10 are also preserved.

Incipit: [1v1] om namaḥ śivāya gurave // om namaḥ śāśvatikānamiajñānaiśvaryamayātmane [...] (KSV I 1,1).

Explicit: [80r17] -yitum iti hi vyāharad vṛttikārah // avayavapadārthah // iti śrībhatțajayamtasya kṛtau nyāyamamjaryām daśamam āhnikam samāptam // śubham astu sarvajagatām parahitaniratā bhavaṃtu bhūtagaṇāh // doṣā prayāmtu śāmtim sarvatra sukhe bhavaṃtu lokāh // śubham // śubham (KSV II 583,4-7).

Notes: The library label on the cover reads " 228 . [corrected to 237 by hand] Nyayamanjari I by Bhattajayanta | Calligraphy I (Big Size) I pp. 160" in type, and "C. No. 1015", and other unintelligible numbers written by hand. Thus it describes the manuscript as being composed of 160 pages, i.e. 80 folios; the mistake may have been caused by a superficial glance at the foliation of the first and last folios only. In the bipartite foliation, in an approximate calculation, the second part must have started again from 1 soon after the preserved fol. 83 at the beginning of NM 5. The original manuscript was possibly already missing NM 11-12, judging from the elaborate colophon at the end of NM 10. The margins of the first four folios are filled with notes, containing passages of the Granthibhanga (see Muroya 2009-2010, pp. 228-229).

Bibliography: Cat. BHU 1971; KKa, p. 118; KKb, p. 135; KKc, p. 60; KKd, p. 129; Muroya (2009-2010, pp. 228-229).

2.18 Varanasi, Sampurnanand Sanskrit Visvavidyalaya, Sarasvati Bhavan Library (SSV 3465)

Saṃvat 1794 (CE 1736-1737); 320; 130 × 240; paper; Devanāgarī; photocopies.

Extent: $\quad$ Contains the complete text. Foll. 1-320 in the original foliation.

Incipit: [1v1] śrīganeśāya namah om svasti om namaḥ śāsvatikānandajñānaiśvaryamayātmane [...] (KSV I 1,1).

Explicit: - -prapannajñānasamkalpakalpavṛkṣāyaśambhave // śrījayaṃtabhațtakrtāyām nyāyamaṃjaryām dvādaśam āhnikam samāptā ceyam nyāyamamjarī // [320v7](KSV II 718,10).

Colophon: [320v8] śubham astu sarveșām lekhakāh samvat 1794 mārgaśīirasu 4 amātyavāra pure (?). 
Notes: $\quad$ In Cat. SC 1902, p. 14, it is described as follows: "Devanāgarī script on paper, foll. 320, Samvat 1794 (CE 1736-1737)”. In this very list it is also confirmed that the manuscript was used as the source of GDh ([...] yasmād vijayanagarasamskṛtasīījasañjiñikāyāị [...] nyāyamanjarīpustakam mudritam). The manuscript contains frequent corrections, interlinear and in margins. Some of these appear to be by a second hand, written in a thinner trait. Several emendations are not clearly visible in the photocopies. The presence of lost emendations can be in many cases inferred from the presence of interlinear correction and reference marks. It is likely that two different hands corrected the manuscript, and it cannot be excluded that one of them may even be Gangādhara's own. The date is written in a second hand. The manuscript is read with some difficulty, because of the thin and transparent paper that reveals the ink of the back side and can hide or blur, particularly, the frequent interlinear corrections.

Bibliography: Cat. SC 1902, p. 14; Cat. SBhL 1962; GDh, Bhūmikā, p. 5.

\section{A Synopsis of the Descriptive List}

In conclusion, the following manuscripts, although explicitly mentioned in catalogues and editions, still need to be located and examined:

- MU RKS 543, Ph 13 and Rā 13.14, attested only in the CC and in the NCC.

- BHU C-4666 is supposedly listed in Cat. BHU 1971, although I could not yet consult this catalogue. Recent attempts to retrieve it failed because it was not found on shelf by the staff at the Library.

- LU 45440, catalogued in Cat. LU 1951, p. 40.

- MyA, a transcript owned by Ātmakūru Dīkșācārya, cited in the Mysore edition. In KSV, vol. I, Prastāvanā, p. i, this document is described as follows: "While engaged in searching for other documents, we heard that there was one document in the Parakāla Mațha in Mysore, but [...] we went there to collect it and we found that this document was not available. Still, we have found that there is now a text owned by Ātmakuru Dīkșācārya which was edited on the basis of that document, [...]". On the basis of this description, a possible conjecture is that MyA may have been a transcription of an unidentified manuscript, as suggested in KKa, p. 117.

The following table provides an overview of the manuscripts surveyed in this paper. The first column indicates the sequential order in which they have been described above. The second column mentions the place where they are currently preserved, the third the manuscript identifier, the fourth the content and the fifth the script $(\mathrm{D}=$ Devanāgarī, $\mathrm{M}=$ Malayālam, $\dot{S}=$ Sāradā). The sixth column cites editions that have used the manuscripts. 
Located manuscripts of the Nyāyamañjarī

\begin{tabular}{llllll}
\hline \multicolumn{1}{l}{ Place } & Identifier & Extent & Script & Editions \\
\hline 1 & Allahabad & GJ 833/52 & NM 1-12 & D & KSV; KKa; KKb; KKc; KKd; \\
& & & & KKe; KKf; KKg; KKh \\
2 & Chennai & AL 70179b & NM 6-12 & M & KSV \\
3 & Chennai & GOML R. 3631a & NM 7-12 & M & KSV; KKa \\
4 & Chennai & GOML R. 3583 & NM 7-12 & M & KSV \\
5 & Göttingen & NSUB MU II 26 & NM 1 & S & KKd \\
6 & Göttingen & NSUB MU I 95 & NM 1 & Ś & KKd \\
7 & Kolkata & AS G-10991 & NM 1-10 & D & None \\
8 & Lucknow & ABhSP 2381 & NM 1-4 & Ś & KKc; KKd \\
9 & Mysore & ORI C-1374 & NM 1-12 & D & KSV1; KSV2; KKg; KKh \\
10 & Pune & AA 5329 & NM 5-7 & D & None \\
11 & Pune & BORI 390/1875-76 & NM 1-12 & S & GDh \\
12 & Pune & DC 10663 & NM 1-7 & D & None \\
13 & Srinagar & ORL 1088 & NM 1-4 & Ś & None \\
14 & Srinagar & ORL 1933 & NM 5-8 & Ś & KKf \\
15 & Srinagar & ORL 2179 & NM 3-4 & S & None \\
16 & Thenjipalam & MDUC 2606 & NM 1-7 & M & KKb; KKc; KKd; KKe; KKf; \\
& & & NM 1-5, 8-9 & D & KKa; KKb; KKc; KKd \\
17 & Varanasi & BHU C-1015 & NM 1-12 & D & GDh \\
18 & Varanasi & SSV 3465 & & & \\
\hline
\end{tabular}

Acknowledgments This paper was written in the context of project M-1160 G-15, July 2009 to June 2011, financed by the FWF (Fonds zur Förderung der wissenschaftlichen Forschung) and based at the Institut für Südasien-, Tibet-und Buddhismuskunde (ISTB), University of Vienna. The project is a critical edition of the sixth chapter of the Nyāyamañjarī of Jayanta Bhatta. I am indebted to several colleagues for the documentary foundation, which is articulate, multi-layered, and gathered in the course of years of work. A systematic mention of the source after every bit of information was too impractical, so I am forced to give credits in a rather general way. First of all, gratitude is due to all the repositories where the manuscripts are preserved; without the collaboration from these repositories, explicitly named in the headings of the manuscripts' descriptions, my research would not have been possible. Most manuscript images and catalogue material were provided by the Nyāya Archive (FWF Projects P-17244 and P-19328) and by the Library of the ISTB. I am grateful to Dominic Goodall, Kei Kataoka, Yasutaka Muroya, Karin Preisendanz, Taisei Shida, Raffaele Torella, and Alex Watson, who kindly shared additional manuscript images, indispensable for the descriptions. I am particularly grateful to Yasutaka Muroya (Leipzig, Project DFG FR2531/4-1), who contributed to my knowledge of the manuscript tradition of the Nyāyamañjari by sharing thoughts, discussing crucial topics, and providing catalogue material and information otherwise unavailable to me. His solid research work on the Nyāyamañjari was a source of inspiration and a bench-mark for accuracy. He also deserves credit for reading this paper and increasing its value with supplementary information, friendly criticism, and precise emendations. Special thanks are due to Elisa Freschi, who read an early draft of the paper and enhanced its value with her insightful remarks.

Open Access This article is distributed under the terms of the Creative Commons Attribution License which permits any use, distribution, and reproduction in any medium, provided the original author(s) and the source are credited. 


\section{Bibliography}

\section{Manuscript Catalogues and Editions, with Abbreviations}

$\begin{array}{ll}\text { ABC } & \text { Klaus L. Janert (1965). An Annotated Bibliography of the Catalogues of Indian } \\ & \text { Manuscripts. Wiesbaden: F. Steiner. } \\ \text { BBC } & \text { Subhas C. Biswas, ed. (1998). Bibliographic Survey of Indian Manuscript Cata- } \\ & \text { logues. Being a Union List of Manuscript Catalogues. Delhi: Eastern Book Linkers. } \\ \text { CC } & \text { Theodor Aufrecht (1962). Catalogus Catalogorum. An Alphabetical Register of } \\ & \text { Sanskrit Works and Authors. Two volumes. Or. ed. 1891, 1896, 1903, in three parts. } \\ & \text { Wiesbaden: Franz Steiner. }\end{array}$

Cat. AL 1911 F. Otto Schrader, ed. (1911). A Preliminary List of the Samskṛt and Prākrt Manuscripts in the Adyar Library. Vol. 1. By the Pandits of the Library. Madras: Adyar Library.

Cat. AL 1926 A. Mahadeva Shastri, ed. (1926). A Catalogue of the Sanskrit Manuscripts in the Adyar Library. Vol. 2.2. Adyar Library Series. By the Pandits at the Library. Madras: Adyar Library.

Cat. AL 1928 T. R. Chintamani, ed. (1928). A Catalogue of the Sanskrit Manuscripts in the Adyar Library. Vol. 2.2. Adyar Library Series. By the Pandits at the Library. Madras: Adyar Library.

Cat. AL 1972 K. Parameswara Aithal, ed. (1972). Descriptive Catalogue of Sanskrit Manuscripts. Vol. 8. Sāṃkhya, Yoga, Vaiśeșika and Nyāya. Madras: The Adyar Library and Research Centre.

Cat. AS 1957 Haraprasāda Śāstrī, ed. (1957). A Descriptive Catalogue of the Vernacular Manuscripts in the Collections of the Royal Asiatic Society of Bengal. Vol. 11. Revised by N. C. Vedāntatīrtha and C. Cakravarti. Kolkata: Asiatic Society of Bengal.

Cat. BHU 1971 Ram Shankar Tripathi, ed. (1971). Descriptive Catalogue of Sanskrit Manuscripts in Gaekwad Library, Bharat Kala Bhavan Library and Sanskrit Mahavidyalaya Library. Varanasi: Banaras Hindu University.

Cat. DC 1888 Shridhar R. Bhandarkar (1888). A Catalogue of the Collections of Manuscripts deposited in the Deccan College. Bombay: Government Central Press.

Cat. GJRI 1967 Umeśa Miśra, ed. (1967). Descriptive Catalogue of Sanskrit Manuscripts in Ganganatha Jha Research Institute. Vol. 1. Allahabad: Ganganatha Jha Research Institute.

Cat. GOL 1922 E. U. (1922). Catalogue of Sanskrit Manuscripts in the Government Oriental Library of Mysore. Mysore: Government Branch Press.

Cat. GOML 1927 (1927). A Triennial Catalogue of Manuscripts Collected During the Triennium 1919-20 to 1921-22 for the Government Oriental Manuscript Library, Madras. Vol. 4.1. Prepared under the orders of the Government of Madras. Madras: Government Press.

Cat. GOML 1938 Kuppuswami S. Sastri and P.P. Subrahmanya Sastri (1938). An Alphabetical Index of Sanskrit Manuscripts in the Government Oriental Manuscripts Library. Vol. 1. Madras: Government Press.

Cat. LA $1970 \quad$ K.A. Subramania Iyer et al. (1970). A Catalogue of Manuscripts in the Akhila Bharatiya Sanskrit Parishad Lucknow. Vol. 2. Compiled by Daulat Ram Juyal. Lucknow: The Akhila Bharatiya Sanskrit Parishad.

Cat. LU $1951 \quad$ Kali Prasad (1951). Catalogue of Oriental Manuscripts in the Lucknow University Library. Lucknow: P.P. Kapur, Ram Kumar Press.

Cat. OUH 1964 Aryendra Sharma et al., eds. (1964). A Catalogue of Sanskrit Manuscripts in the Osmania University Library. Hyderabad: The Sanskrit Academy, Osmania University.

Cat. Report 1875 Georg Bühler (1877). Detailed Report of a Tour in Search of Sanskrit Mss. Made in Kashmir, Rajputana and Central India. Extra number of the Journal of the Bombay branch of the Royal Asiatic Society. Bombay-London: Society's Library, Town hall (Bombay). Trübner and Co. (London). 
Cat. SBhL 1962

Cat. SC 1902

Cat. SORL 1989

Cat. VOHD 1970

GDh

$\mathrm{KKa}$

$\mathrm{KKb}$

$\mathrm{KKc}$

KKd

$\mathrm{KKe}$

KKf

$\mathrm{KKg}$

$\mathrm{KKh}$

KSV

NCC Abbreviations

NCC 1

NCC 3

NCC 10
(1964). A Descriptive Catalogue of Sanskrit Manuscripts Acquired for and Deposited in the Sanskrit University Library (Saraswati Bhavan), Varanasi, During the Years 1791-1950. Vol. 8. Nyāya-Vaiśeșika. Varanasi: Shri Vishveshwara Press, Sanskrit University.

(1902). List of Sanskrit, Jaina and Hindi Manuscripts. Purchased by Order of Government and Deposited in the Sanskrit College, Benares, during 1897, 1898, 1899, 1900 and 1901. Allahabad: Government Press, U.P., of Agra and Oudh.

Sri Kanth Kaul and D. N. Yach, eds. (1989). A Catalogue of Sanskrit Manuscripts. Srinagar: The Research And Publication Department, Jammu \& Kashmir Government.

Klaus L. Janert and N. Narasimhan Poti, eds. (1970). Indische und Nepalische Handschriften. Vol. 2.2. Verzeichnis der Orientalischen Handschriften in Deutschland. Wiesbaden: Franz Steiner.

Gañgādhara Śāstrī Tailaṅga, ed. (1895). The Nyāyamañjarī of Jayanta Bhațta. Vizianagram Sanskrit Series 8. Benares: E.J. Lazarus and Co.

Kei Kataoka (2003). "Critical Edition of the Vijñānādvaitavāda Section of Bhața Jayanta's Nyāyamañjarī’. In: The Memoirs of the Institute of Oriental Culture 144, pp. 115-155.

Kei Kataoka (2004). "Critical Edition of the Āgamaprāmāṇya Section of Bhața Jayanta's Nyāyamañjarı̄’. In: The Memoirs of the Institute of Oriental Culture 146, pp. 131-175.

Kei Kataoka (2005). "Critical Edition of the Ísarasiddhi Section of Bhatta Jayanta's Nyāyamañjarı̄”. In: The Memoirs of the Institute of Oriental Culture 148, pp. 79-132.

Kei Kataoka (2007a). "Critical Edition of the Śāstrārambha Section of Bhațta Jayanta's Nyāyamañjarī”. In: The Memoirs of the Institute of Oriental Culture 150, pp. $123-170$.

Kei Kataoka (2008). “A Critical Edition of Bhațta Jayanta’s Nyāyamañjarī: The Section on Kumārila's Refutation of the Apoha Theory". In: The Memoirs of the Institute of Oriental Culture 154, pp. 1-31.

Kei Kataoka (2009). “A Critical Edition of Bhatța Jayanta’s Nyāyamañjarī: The Buddhist Refutation of Kumārila's Criticism of Apoha Theory”. In: The Memoirs of the Institute of Oriental Culture 156, pp. 1-41.

Kei Kataoka (2010). "A Critical Edition of Bhața Jayanta's Nyāyamañjarī: Jayanta's View on Jāti and Apoha". In: The Memoirs of the Institute for Advanced Studies on Asia 158, pp. 61-113.

Kei Kataoka (2011). “A Critical Edition of Bhațta Jayanta’s Nyāyamañjarī: The Buddhist Refutation of Jāti". In: The Memoirs of the Institute for Advanced Studies on Asia 160, pp. 1-43.

K. S. Varadācārya, ed. (1969-1983). Nyāyamañjarī: with Tippaṇī Nyāyasaurabha. Two volumes. Mysore: Oriental Research Institute.

NCC, ed. (1984). Catalogue, Lists, etc., Used in the New Catalogus Catalogorum with the Abbreviations used for them. Madras: University of Madras. Revised version of the introductory chapter of the 1949 edition of the NCC.

V. Raghavan, ed. (1968). New Catalogus Catalogorum. An Alphabetical Register of Sanskrit and Allied Works and Authors. Revised Edition (a). Vol. 1. Madras: University of Madras. Or. ed. 1949, with a preface by C. Kunhan Raja. A revised edition of that first volume of the NCC with an addition of more than 100 pages. V. Raghavan, ed. (1967). New Catalogus Catalogorum. An alphabetical register of Sanskrit and allied works and authors ( $\bar{u}$-kārtavīrya $\left.{ }^{\circ}\right)$. Vol. 3. Madras: University of Madras.

K. Kunjunni Raja, ed. (1978). New Catalogus Catalogorum. An alphabetical register of Sanskrit and allied works and authors $(n \bar{a}-n v \bar{a})$. Vol. 10. Madras: University of Madras. 


\section{Secondary Sources}

Burnell, A. C. (1878). Elements of South-Indian Paleography from the Fourth to the Seventeenth Century A.D. Being an Introduction to the Study of South-Indian Inscriptions and Mss. Second enlarged and improved edition. London: Trübner \& Co.

Coward, H., \& Kunjunni Raja, K. (Eds.). (2001). Encyclopedia of Indian philosophies (Vol. 5). The philosophy of the grammarians. New Delhi: Motilal Banarsidass. Or. ed. 1990.

Dezsô, C. (Ed.). (2005). Much Ado About Religion. The Clay Sanskrit library. New York: New York University Press. Sanskrit text and translation of Bhața Jayanta's Agamadambara.

Frauwallner, E. (1936). Beiträge zur Geschichte des Nyāya: I. Jayanta und seine Quellen. In Wiener Zeitschrift für die Kunde des Morgenlandes 43 (pp. 263-278). (Reprinted in Kleine Schriften, hrg. G. Oberhammer \& E. Steinkellner, Wiesbaden: Franz Steiner Verlag GMBH, 1982, pp. 145-160.)

Grünendahl, R. (2001). South Indian scripts in Sanskrit manuscripts and prints. Wiesbaden: Harassowitz Verlag.

Gupta, B. (1963). Die Wahrnehmungslehre in der Nyāyamañjarī. Walldorf-Hessen: Verlag für Orientkunde Dr. H. Vorndran.

Hacker, P. (1951). Jayantabhaț̣a und Vācaspatimiśra, ihre Zeit und ihre Bedeutung für die Chronologie des Vedānta. In Alt-und neuindische Studien 7. Hamburg: Cram, de Gruyter. (Reprinted in Kleine Schriften, hrg. L. Schmithausen, Wiesbaden: Franz Steiner Verlag GMBH, 1978, pp. 110-119.)

Kataoka, K. (2007b). Was Bhaț̣a Jayanta a Paippalādin? In A. Griffiths \& A. Schmiedchen (Eds.), The Atharvaveda and its Paippalādaśäkhā. Geisteskultur Indiens: Texte und Studien 11 (pp. 319-333). Aachen: Shaker Verlag.

Matilal, B. K. (1977). Nyāya-Vaiśeșika. A History of Indian Literature 6. Wiesbaden: Otto Harrassowitz.

Muroya, Y. (2009-2010). A Study on the Marginalia in Some Nyāyamañjarī Manuscripts: The Reconstruction of a Lost Portion of the Nyāyamañjarīgranthibhanga. In Wiener Zeitschrift für des Kunde Südasiens 52-53 (pp. 213-267).

Oberhammer, G. (1962). On the sources in Jayanta Bhațta and Uddyotakara. In Wiener Zeitschrift für die Kunde Süd-und Ostasiens 6 (pp. 91-150).

Petrucci, A. (2001). La descrizione del manoscritto: storia, problemi, modelli (revised second edition). Roma: Carocci.

Potter, K. H. (Ed.). (1995). Encyclopedia of Indian philosophies (Vol. 2). The tradition of NyāyaVaiśeșika up to Gañgeśa. New Delhi: Motilal Banarsidass. Or. ed. 1977.

Sanderson, A. (2007). The Śaiva Exegesis of Kashmir. In D. Goodall \& A. Paoux (Eds.), Mélanges tantriques à la mémoire d'Hélène Brunner/Tantric Studies in Memory of Hélène Brunner. Collection Indologie 106. Pondicherry: Institut Français d'Indologie.

Shullian, D. M. (1981). A revised list of manuscripts of Valerius Maximus. In R. Avesani, M. Ferrari, \& G. Pozzi (Eds.), Miscellanea Augusto Campana (Vol. 2, pp. 695-728). Padova: Antenore.

Slaje, W. (1986). Untersuchungen zur Chronologie einiger Nyāya-Philosophen. In Studien zur Indologie und Iranistik 11-12 (pp. 245-278).

Slaje, W. (2012). Wann, wo und weshalb schrieb Bhațta Jayanta seine „Blutenrispe am Baum des Nyāya“"? In R. Steiner (Ed.), Highland Philology. Results of a Text-Related Kashmir Panel at the 31st DOT, Marburg 2010. Halle: UVHW.

Timpanaro, S. (2003). La genesi del metodo del Lachmann. Or. ed. 1963. Torino: UTET. 